\title{
ARBITRATION AS A MECHANISM TO RESOLVE ISLAMIC BANKING DISPUTES IN MALAYSIA: CHALLENGES AND DRAWBACKS
}

\author{
${ }^{1}$ Mohamad Fateh Labanieh, ${ }^{2}$ Mohammad Azam Hussain \& \\ ${ }^{3}$ Nazli Mahdzir \\ ${ }^{1,2}{ }^{3}$ School of Law, College of Law, Government and \\ International Studies, Universiti Utara Malaysia \\ fatih.labanie@gmail.com; hmazam@uum.edu.my; \\ mnazli@uum.edu.my
}

Received: 14/11/2018 Revised: 8/4/2019 Accepted: 24/6/2019 Published: 31/7/2019

\begin{abstract}
Malaysia has shown tremendous progress in the arena of Islamic banking and the finance industry, and has become an essential Islamic financial hub within the region. The comprehensive legal framework consisting of legislation and dispute resolution mechanisms have been crucial elements that ensured the robust development of the industry. The court system and arbitration are two significant platforms for the settlement of Islamic banking disputes that are brought before them. However, the court system has been widely favoured compared to the arbitration, even though both approaches have almost identical roles. Therefore, one question arises; why is arbitration less preferred compared to the court system? By using legal research methods, this article seeks to analyse the challenges and drawbacks that faces the current arbitration framework when dealing with Islamic banking disputes. This study suggests that the Malaysian arbitration framework faces several challenges such as, issues regarding high-cost, high-formality, less-speed, and the uncertainties when referring any Shariah matters to the Shariah Advisory Council. This article suggests that some improvements should be made by the relevant authorities and establish the necessary statutory amendments to strengthen the role of arbitration in Malaysia as a complementary forum to the court system in settling Islamic financial disputes.
\end{abstract}


Keywords: Arbitration, Court, Islamic banking and finance, Shariah law, Shariah advisory council.

\section{INTRODUCTION}

The growth of the Islamic finance industry in Malaysia has been extraordinary, and has been growing $50 \%$ faster than the conventional banking system (Zakaria, 2013). Islamic banking has demonstrated various possibilities and has been widely preferred as a reasonable alternative to the conventional banking system. Moreover, the Islamic banking system has been accepted in several jurisdictions and has proved its effectiveness globally (Ab. Halim, 2011). The establishment of Tabung Haji in 1962 (previously known as Perbadanan Wang Simpanan Bakal-bakal Haji) paved the way for Malaysia to establish itself within the Islamic finance industry (Kawamura, A., 2017). In 2017, the total assets of the Malaysian Islamic banking amounted to RM610.52 billion (Shen, 2017). The Malaysian Islamic financial system comprises of three major sectors, which are Islamic banking, takaful, and Islamic capital market (Hassan \& Hussain, 2011).

The establishment of the Islamic finance industry in Malaysia was not limited to the economical aspects, but was also incorporated into the legal system. The Malaysian government paid considerable attention to enhance the legal framework of the Islamic banking by ratifying the Central Bank of Malaysia Act 2009 (Act 372) (hereinafter referred to as "CBMA 2009") and Islamic Financial Services Act 2013 (Act 759) (hereinafter referred to as "IFSA 2013"), in order to maintain its position as a global hub for the Islamic finance industry. The dispute resolution legal framework in the context of Islamic banking is divided into two main mechanisms; litigation which includes the courts, and alternative dispute resolution (hereinafter referred to as "ADR") comprising of arbitration and mediation.

This article provides an overview on the legislative framework governing arbitration in resolving Islamic banking disputes and its associated drawbacks and challenges. Therefore, section one provides a concise summary of the history on the use of the arbitration mechanism in the Islamic era and explains the arbitration legal 
framework in resolving the Islamic banking dispute in Malaysia. Section two discusses the drawbacks and hurdles linked with the use of arbitration in handling Islamic banking cases.

\section{ALTERNATIVE DISPUTE RESOLUTION IN MALAYSIA}

In general, arbitration has been practised within the Muslim community for over 1400 years, as the religion of Islam continues to underline the concept of harmony rather than hostilities and encourage peaceful compromise in any dispute instead of confrontation (Dahlan, 2018). The concept of tahkim in Islamic law, refers to arbitration. Although tahkim as a dispute resolution mechanism has been extensively practised in the pre-Islamic Arabia, the emergence of the Islamic religion has given it substantial support and provided more efficiency to its procedures in order to assure justice and fairness (Oseni, 2009). Furthermore, several Qur'anic verses have proved and supported the use of tahkim mechanism in handling any disputes (Al-Qur'an, 4:58; 4:65).

Within the Malaysian context, ADR is not something new to the people of Malaysia, as it has been ingrained and is part of the culture. Moreover, it has been proposed that the components of ADR have appeared in the communities of Malays (Wan Muhammad, 2008), Chinese (John Shijan, 1999) and Indians (Lahoti, 1999). Typically, arbitration has been remarkably adopted as a dispute resolution mechanism, since Malaysia has appeared progressively as one of the famous arbitration centres in the Asia-Pacific region and is recognized as a friendly arbitration seat (Leong \& Mann, 2012).

The Malaysia arbitration system is regulated by the Arbitration Act 2005 (Act 646) (hereinafter referred to as "Act 646") and several rules issued by the Asian International Arbitration Center (hereinafter referred to as "AIAC"). When dealing with Islamic banking disputes that are referred to AIAC, reference should be made to I-Arbitration Rules 2018.

On $15^{\text {th }}$ March 2006, Act 646 was implemented, and was essentially derived from the United Nations Commission on International 
Trade Law (UNCITRAL) Model Law on International Commercial Arbitration. In addition, the principal purpose of Act 646 is to reinforce the international harmony and consistency of the arbitral bodies that have been framed in accordance to the UNCITRAL.

Act 646 has brought forth several important amendments that need to be highlighted and appreciated. Among these amendments is $\mathrm{s} .8$ that limits the intervention of the Malaysian High court in the arbitral awards and proceedings. Moreover, s.10 authorises the Malaysian High court to grant mandatory stay-of-court proceedings if an application has been made by the party and the arbitration agreement is valid and capable of being performed. Other than that, s.18 grants the arbitral tribunal an authority, after obtaining the parties' consents in the arbitral agreement, to decide on matters concerning preliminary objection and the validity of the arbitral agreement. Finally, s.19 allows the arbitral tribunal along with the Malaysian High court to order interim measures.

Regarding I-Arbitration Rules 2018, the AIAC, ${ }^{1}$ has released a set of rules previously known as the Rules for Arbitration of Kuala Lumpur Regional Centre for Arbitration (Islamic Banking and Financial Services) 2007 (hereinafter referred to as "IBFSA Rules 2007") to ensure the adoption of arbitration mechanism to resolve the disputes that resulted from Islamic financial services. IBFSA Rule 2007 is applied to arbitrate any commercial contract, business arrangement or transaction based upon Shariah principles (IBFSA Rules 2007, rule 1(3). The IBFSA Rules have been continually amended, and the current amendment is known as the AIAC I-Arbitration Rules 2018 (hereinafter referred to as "I-Arbitration Rules 2018").

I-Arbitration Rules 2018 have been designed to adequately cater for and meet the increased demands and needs of the commercial transaction based on the Islamic principles. Hence, this had led to

the recognition of the rules and have been receiving considerable attention from around the world. As evidenced by this fact,

Asian International Arbitration Center (formerly known as Kuala Lumpur Regional Center of Arbitration) was established in 1978 under the auspices of the Asian-African Legal Consultative Organization, and is the first regional centre that was founded in Asia to provide institutional support as an independent and neutral venue for the conduct of international and domestic arbitration proceedings in Asia. 
I-Arbitration Rules 2018 have been internationally recognized after receiving the prestigious Global Arbitration Review Award for 'Innovation by An Individual or Organisation' (The Star, 2013). Moreover, the I-Arbitration Rules 2018 have been lauded as the first arbitration rules in the world which established exclusivity and particularity to the settlement of disputes generated from commercial contracts that comprises of Shariah issues.

The letter 'I' in 'I-Arbitration' is acknowledged within the Islamic world as an indicator that the provided service or product is Shariah-compliant (Hodges, Kaplan \& Godwin, 2012). The AIAC I-Arbitration Rules 2018 is categorised into three main parts. Part I is AIAC I-Arbitration Rules which is comprised of 19 rules. Part II is the UNCITRAL Arbitration Rules that consists of 43 articles. Part II is further divided into four main sections: Section I (Introductory Rules); Section II (Composition of the Arbitral Tribunal); Section III (Arbitral Proceedings); and Section IV (The Award). Part III provides three main schedules to the rules. Furthermore, if there is any conflict that exist between Part I and Part II, the former will be utilised (I-Arbitration Rules, rule 1(3)). Accordingly, Act 646 or I-Arbitration Rules 2018 can be applied to all commercial disputes including disputes that involve Islamic finance, for which the disputants have agreed in writing to submit their dispute to arbitration.

Arbitration can be classified into four types, which are domestic arbitration, international arbitration, ad-hoc arbitration, and institutional arbitration. International arbitration is implemented when one of the parties to an arbitration agreement, at the time of the conclusion of that agreement, has its place of business in any country other than Malaysia.

Domestic arbitration refers to any arbitration that is not categorised as international arbitration. Ad-hoc arbitration is the type of arbitration that is not administered by an arbitral institution or the arbitral agreement does not designate an arbitral institution (Rajoo, 2009). Succinctly, disputants will mutually agree on the arbitral procedures to deal with the dispute. Institutional arbitration refers to the arbitral agreement that appoints an arbitral institution to administer the 
arbitration (Rajoo, 2009). Typically, institutional arbitration is the arbitration which is administered by any arbitration institutions.

In this regard, it can be argued that if the parties agree on their arbitration agreement to employ Act 646, the following arbitration will be an ad hoc arbitration because it is not administered by any arbitration institution such as the AIAC and therefore, the parties will have full authority to determine all aspects of the arbitration. This in turn allows parties to determine the applicable procedural rules and the appointment of the arbitrators. However, I-Arbitration Rules 2018 is considered as an institutional arbitration as the parties have already agreed in the arbitration agreement to follow the set of arbitration rules provided by AIAC. In other words, the parties that partake in the institutional arbitration will only need to submit their disputes to the AIAC, which will intervene and manage the arbitral proceedings in accordance to its set of arbitration rules.

\section{ARBITRATION CHALLENGES IN ISLAMIC BANKING DISPUTES}

In Malaysia, the number of Islamic banking disputes have increased in correlation with the growth of the Islamic finance industry both domestically and internationally. Hence, it has been imperative to support this growth with a coherent arbitration framework that can mitigate the tension within the Islamic finance industry and bring about justice for the potential disputants. Literature have suggested that the use of arbitration in the Islamic finance industry in Malaysia has been advocated (Al-Shibli, 2017). This is due to the advantage that it provides such as, avoiding the application of non-Shariah law on the Islamic banking cases (Abu Backer, 2017). Arbitration in Islamic banking disputes is still facing real challenges that need prompt intervention from the competent authorities to enhance the sustainability in Islamic banking and strengthen the current legislative framework that governs arbitration.

\section{High-Cost, High-Formality and Less-Speed}

The increased use of arbitration and the active engagement of lawyers in arbitral procedures have made arbitration unappealing and has been practised similarly to litigation, subsequently making 
arbitration a less attractive approach for settlements (Syed A. Rahman $\&$ Mokhtar, 2017). Therefore, arbitration becomes an inappropriate mechanism for the Islamic banking disputants to settle their disputes efficiently. Several components play a fundamental role in creating unnecessary burden to the disputants, followed by the exceedingly high cost of utilizing arbitration. One of which is that disputants in the arbitration cases are expected to pay the arbitrators' expenses and fees, which are very high (Abdul-Qadir Zubair, 2014).

The high fee for arbitrators was highlighted in a speech that was delivered by Idid (2004), in which he encouraged Malaysian judges to participate as arbitrators in the arbitral tribunal and illustrated the financial advantages that can be exploited by them. He mentioned that;
"The fees in arbitration can be huge. In one case, and there are a thousand others, an arbitrator's fees enabled him to buy an apartment in the UK and a large piece of land in an Asian country. I share this with you because the majority here are judges and so look forward to retiring and getting into their second retirement".

Another factor that contributes to the high cost for arbitration is embodied in the need for parties and arbitrators to travel around the world to attend arbitration sessions (Kohler \& Schultz, 2005). This is mainly observed in the international arbitration cases that include disputants from different jurisdictions. However, it is estimated that the increase in the application of technology would play a vital role in mitigating the cost of arbitration.

Subsequently, based on the request of either the disputant or the arbitral tribunal, the parties under the auspices of AIAC are expected to pay additional expenses, such as the interpretation facilities, proper accommodation for the arbitral tribunal, transcription services, secretarial assistance, and video or teleconferencing (I-Arbitration Rule 2018, rule 12). Particularly, in Islamic banking cases, the parties shall bear the "Expenses reasonably" incurred in reference to the relevant council or Shariah expert appointed by the arbitral tribunal (I-Arbitration Rule 2018, rule 14(b)). Hence, it can be assumed that these expenses will exhaust the disputants and give 
them clear reasons to refuse the use of arbitration in their disputes. Abraham (2006) suggested that, "it is a misconception to think that arbitration in particular, is less expensive than litigation." Moreover, Rashid (2008) proposed that "arbitration may be far costlier and more protracted than litigation."

Other than that, high fees and expenses are also required to be paid by the disputants in any arbitration case, under the auspices of AIAC. After the commencement of arbitration, the disputants must pay an advance deposit within 21 days, starting from the day the disputants receive the request from the AIAC (I-Arbitration Rules, rule 15(2)). In the event that any of the parties fail to provide payment for the advance deposit, the Director will provide another opportunity for the insolvent party to make the payment. If the disputants fail to settle the payment, the arbitral tribunal will not proceed to the arbitral proceedings (I-Arbitration Rules, Rule 15(3)).

In traditional arbitration, the submission of arbitration documents and arguments by those that are involved in the arbitration dispute is usually carried out through traditional ways, rather than through the use of electronic means. However, in some occasions, the use of papers and documents in arbitration cases can be substantial, that can lead to additional expenses as these documents will need to be constantly transported between the parties while requiring huge storage spaces to preserve them.

In addition, parties prefer to use the arbitration mechanism due to its informality and commercial approach in resolving their dispute (Goode, R., 1992). Therefore, the parties frequently expect arbitral proceedings to be informal compared to court proceedings, as this allows them to not hold an oral hearing (Arbitration Act 2005, s. 26). However, the feature of informality, which usually accompanies arbitration no longer exists as it should (Abdul-Qadir Zubair, 2014), because arbitrators on some occasions have shown tendencies toward a greater focus on formal requirements (Welser \& Wurzer, 2008). For instance, arbitrators strictly follow the "chess-clock principle" with regards to witness testimonies (Meyer, 2011). This in turn causes the parties to go through several processes before the rendering of an arbitration decision by the arbitral tribunal. Hence, it 
is presumed that the consequence of the increased level of formality in the arbitration procedures would be more time-consuming.

Moreover, the Islamic banking cases which go through the arbitration mechanism are vulnerable to the risk of being delayed in their disposal. On some occasions, the arbitral tribunal may contain more than one arbitrator who are unable to agree on a fixed hearing schedule. Consequently, this causes unnecessary delay to the parties.

Likewise, the issues of less-speed and high-cost in international commercial arbitration are not only confined to Malaysia, but have been global obstacles and was presented in the International Arbitration Survey 2015. From the survey, it was deduced that $68 \%$ and $36 \%$ of the respondents agreed that the cost and speed respectively, are the worst aspects of international commercial arbitration (Friedland \& Mistelis, 2015).

Therefore, to protect the sustainability of Islamic banking and mitigate the burden on parties to have access to justice in Islamic banking disputes in Malaysia, the relevant authority should take serious action to ensure that the arbitration mechanism is able to cater to the parties' needs, and fulfil the nature of Islamic banking cases that need to be resolved quickly, inexpensively and informally.

\section{Non-Legal Obstacles to the Use of Arbitration by Parties}

The other obstacle that hinders the effectiveness of arbitration is originally a result of non-legal factors that is related to the disputants. On some occasions, the disputants who prefer the use of the arbitration method assume that their choice for arbitration may be perceived as weakness. In general, ADR and arbitration paves the way for a 'Win-Win' situation as the adversarial feelings are far lesser compared to the court system, which is more adversarial and leads to the 'Win-Lose' situation (Miskam \& Abd Hamid, 2011). However, it is impossible to overlook the problem of bringing both parties to attend the sessions of ADR and arbitration because of hatred or deep negative feelings that may discourage the disputants to reach any compromising solution (Kawamura, 2017). As feelings and emotions are part of human nature, it is difficult to change human characteristics when they are based on bad feelings and behaviour. 
On the other hand, these negative feelings can be alleviated easily by avoiding any physical presence between the disputants.

Furthermore, the nature of arbitration is based on the "party autonomy" principle that suggests that arbitration is not compulsory between the parties unless they agree to submit their dispute to the arbitration. However, the use of arbitration in the Islamic banking disputes is somewhat difficult, particularly in the case where the arbitral clause is not agreed upon by both parties before the dispute arises (Olayemi \& Al-Zabyani, 2014). However, it is not advisable to force the disputants to use arbitration only, as there are other dispute resolution mechanisms such as the court or mediation. In addition, it is important for disputants to be able to choose the mechanism to resolve their problems as to not lead to a breach of the parties' rights to choose what is beneficial to them. On the other hand, it is necessary to provide an understanding of the advantages of arbitration to potential disputants, and subsequently include the arbitration clause in Islamic banking contracts along with the court option as this could indirectly lead to an increase in the parties' confidence in arbitration as a valid and legitimate method for resolution.

\section{Uncertainty in Referring any Shariah Matter to Shariah Advisory Council}

CBMA 2009 is among the statutes that governs the Islamic banking industry in Malaysia. Pursuant to CBMA 2009, with reference to the Shariah Advisory Council (hereinafter referred to as "SAC") and any published rulings by SAC as an obligatory duty on the part of the arbitrator or judge, will use the word "shall" in cases that include any Shariah issue (CBMA 2009, s.56). Additionally, the decision of the SAC is binding on the arbitrator and judge (CBMA 2009, s.57).

SAC is obliged by the reference manual to render its decision within 90 days from the start of the day of registration of an arbitrator referral, unless there is any uncontrollable or unforeseen event (Lee \& Oseni, 2015). According to the general rule, SAC must issue its decision within the maximum of 90 days commencing from the day of registration of an arbitrator referral. However, the exception to the rule is that if there happens to be any unpredictable event, the time limit (90 days) may be extended. 
There is a total of five stages that are carried out in any situation when a Shariah matter is referred to the SAC. First, the arbitrator will refer the questions to the SAC through the Secretariat of SAC. Then, the Secretariat will conduct preliminary analysis and research. Subsequently, the analysis and research conducted by the Secretariat will be presented in the SAC meeting for its ruling. The SAC will then make the decision regarding the matters that were referred to them, and a record will be made by the Secretariat. Finally, the decision of the SAC, as approved by the Chairman of SAC, will be notified to the arbitrator (Engku Ali \& Oseni, 2017).

Diagram 2: The process of referring Shariah matters to the SAC by the arbitrator under Reference Manual for Arbitrators for Referrals to $\mathrm{SAC}$

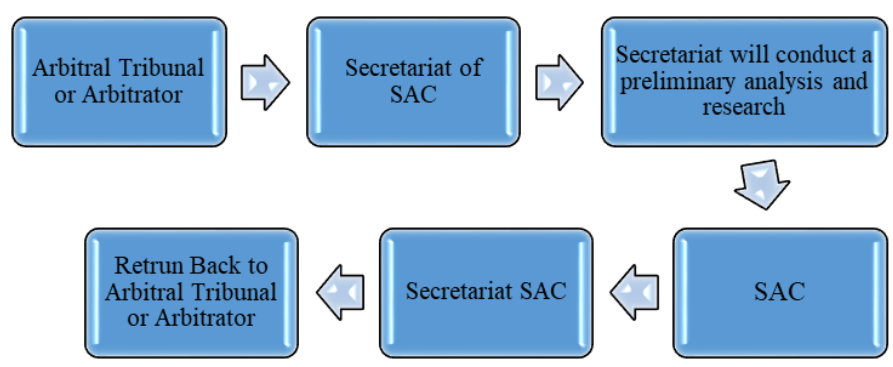

Note: SAC should issue its decision within 90 days starting from the day of registration of an arbitrator referral unless there is an uncontrollable unforeseen event

Furthermore, any reference to the Shariah council or expert by the arbitrator can be conducted in two situations. Firstly, it is when the arbitrator wants to give an opinion regarding the question of the existence of a Shariah issue (I-Arbitration Rule 2018, rule 11(1)(A)). Secondly, it is when the arbitrator wants to give a decision regarding the question of the existence of a Shariah issue (I-Arbitration Rule 2018, rule 11(1)(B)).

However, Rule 11(1) of I-Arbitration Rules 2018 is futile regarding the obligatory duty of the arbitrator to refer any Shariah issue to SAC or Shariah expert. It does not compel the arbitrator to refer any Shariah matter to SAC or Shariah expert. However, it gives the arbitrator the right to choose, by using the word "may". 
Moreover, it has been recommended that sections 56 of the CBMA 2009 should override Rule 11 in I-Arbitration Rules 2018, if the location for arbitration is in Malaysia. This is because the CBMA 2009 is a statute, while the I-Arbitration Rules 2018 is a delegated legislation (Mohamed et al, 2015). Consequently, the arbitrator is obligated by statutory duty to refer to the SAC or Shariah expert for its ruling when Malaysia is the country for arbitration. In contrast, when Malaysia is not the country for arbitration, the arbitrator does not have to refer to the SAC or Shariah expert for its ruling, based on its statutory duty. However, this notion is still subjected to the parties' agreement (party autonomy) on whether they should refer any Shariah issue to the SAC (Mohamed et al, 2015).

The authors failed to identify any rule inside the I-Arbitration Rules 2018 that explains the process of referring a Shariah matter to the SAC by the arbitrator. Therefore, the same process that is provided by the Reference Manual mentioned above is used to highlight the differences regarding the required time for the SAC to present its ruling.

Diagram 3: The process of referring Shariah matter to SAC by the arbitrator under I-Arbitration Rule 2018 and Reference Manual for Arbitrators for Referrals to Shariah Advisory Council of BNM

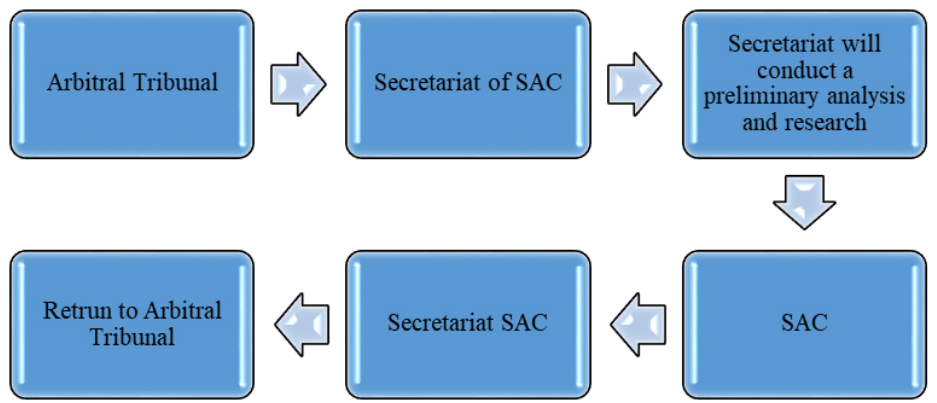

Note: The relevant Council or Shariah expert shall deliver its ruling within the period of 60 days from the date the reference is made

In this regard, it is considered that Rule 11(6) and (7) of I-Arbitration Rules 2018 have created two controversial problems. First, it has given more power to the arbitrator to proceed with the case 
by allowing him/her to issue a binding decision on a dispute that contains a Shariah matter, when the SAC or Shariah expert has failed to answer the arbitrator's question within 60 days from the start of the date when the reference was made.

Second, there exist a lack of harmony and conformity between Rule 11(6) of I-Arbitration Rules 2018 and the Reference Manual for Arbitrators for Referrals to SAC. The former states that "the relevant Council or Shariah expert shall deliver its ruling within the period of 60 days from the date the reference is made". However, the latter mentions that the SAC is obliged by the manual to render its decision during the 90 days from the start of the day of registration of an arbitrator referral, unless there is any uncontrollable or unforeseen event.

The uncertainty in Rule 11 of I-Arbitration Rule 2018 may have affected the entire Islamic Finance industry negatively as there is little doubt that the establishment of the SAC is an indirect plot to cover some problems, such as the lack of competency and expertise in the arbitral tribunals with regard to issuing a decision on any case which includes any Shariah matter (Olayemi, Mahmood \& Buang, 2017). For example, what would happen if the arbitrator is a retired judge with a common law background, and the SAC did not answer the referred question within its duration as stated in the I-Arbitration Rule 2018 (60 days)? The consequence would be devastating not only to the parties who were denied justice from the court judges that lack the necessary experience to understand the complexities of Islamic banking cases, but also to the Islamic banking players that may be reluctant to use the I-Arbitration Rules 2018 under the auspices of AIAC. Hence, the I-Arbitration Rule 2018 should be in line with the reference manual for arbitrators for referrals to Shariah Advisory Council of BNM, through the amendment of rule 11.

\section{Bias in Arbitration Mechanism}

Another aspect that contributes to the decreasing application of arbitration is the bias of arbitrators who did not perform their obligations fairly. It is unusual for an arbitrator to show his/her prejudice or antipathy against one of the parties (Rashid, 2005). The risk of the ethnic or racial bias and discrimination is relatively 
common as there are numerous reported cases that have shown bias from arbitrators towards parties from Africa and Asia (Asouzu, 2011). Hence, it has been challenging to achieve justice when arbitration disputes involve parties from different races, ethnics and religions.

In a related case that took place in Malaysia on 25 July 2013, Yusof Holmes Abdullah, a British national and arbitrator in the AIAC, was charged with cheating the AIAC Director by dishonestly inducing the AIAC into believing that his proposed 'Statement of Independence' was true. Yusof provided a false 'Statement of Independence' to the Director of AIAC in order to arbitrate the dispute between JMR Construction Sdn Bhd and Syarikat Nanjing Changjiang Waterway Engineering Bureau, and to instigate the AIAC to rule in favour for JMR in the arbitration proceedings. Mohd Nasir J referred to correspondences between Yusof and staff from JMR Construction, a company he had previously consulted. Yusof was sentenced to six months in jail and fined RM20,000 by the Sessions Court (Karim, 2017). In this case, the arbitrator did not disclose his relationship with "JMR Construction Sdn Bhd" and was in fact biased, in favour of JMR Construction Sdn Bhd. The plaintiff (Syarikat Nanjing Changjiang Waterway Engineering Bureau) had full authority and the right to challenge the arbitrator according to s.14(1)(2) and (3) (a) of Act 646 and rule 5 of I-Arbitration Rules 2018.

Many have speculated that the preceding case would ruin the AIAC's reputation. However, it was observed that that AIAC was stringent when protecting its reputation as a dependable forum for arbitration. On 23 June 2013, the AIAC signed the Corporate Integrity Pledge (CIP) along with 40 other multinational corporations that committed to impartial tribunal proceedings and to combat corruption in the arbitration field.

With regards to the international context, some international organisations and arbitration centers have issued specific rules to avoid bias in the arbitration mechanism which was previously prone to the miscarriage of justice and the erosion of trust between the parties that employed the arbitration mechanism. For instance, the International Chamber of Commerce (ICC) Rule 13(5) of Rules of Arbitration 2012 stipulates that "the sole arbitrator or the president 
of the arbitral tribunal shall be of a nationality other than those of the parties."

Thus, bias has become a serious problem and should not be dismissed as various national and international laws, and conventions have already enacted several rules to mitigate the issue. Furthermore, legislators should impose various measures that are able to protect the arbitration mechanism from further exploitation of bias.

\section{Amiable Composition}

In 1806, the amiable composition concept was implemented for the first time in the French Code of Civil Procedure of 1806 and the Napoleonic Code (Herboczková, 2008). The amiable composition is often defined synonymously with arbitration in equity or ex aequo et bono (Herboczková, 2008). Generally, the literature distinguishes the differences between the two concepts. The amiable composition means an arbitrator decides the dispute before him in accordance with the legal principles and laws. Moreover, the arbitrator has the authority to adjust the effect of non-mandatory legal provisions. Meanwhile ex aequo et bono means the settlement of dispute out of the law, in accordance with moral principles. Therefore, in ex aequo et bono, an arbitrator is authorised to ignore the non-mandatory and mandatory rules, provided that they conform to international public policy (Herboczková, 2008).

The classic common law has rejected the application of the amiable composition because the arbitrator should resolve the dispute according to the constitutional laws, case laws, customary law, and legal norms, without taking into account their own equity (Yu, 2008). However, the amiable composition or ex aequo et bono can be applied today by the arbitrator to decide a resolution for the dispute according to fairness and justice rather than applying the rules of the law, but only when agreed upon by both parties.

For example, article 28(3) of UNCITRAL Model Law on International Commercial Arbitration 1985 states that;

'The arbitral tribunal shall decide ex aequo et bono or as amiable composition only if the parties have expressly authorised it to do so.' 
In the Malaysian context, there is no restriction or provision for the use of the amiable composition or ex aequo et bono in the Arbitration Act since the authority lie with the parties (Alam, 2014). However, Rule 35(2) Part II of I-Arbitration Rule 2018 is more clear in this regard as it states that;

'The arbitral tribunal shall decide as amiable compositeur or ex aequo et bono only if the parties have expressly authorised the arbitral tribunal to do so.'

Hence, it seems that the arbitrator's power is limited through the application of the amiable composition. Meanwhile, rule 35(2) of I-Arbitration Rules 2018 is not fully derived from Islamic law, as the application of the amiable composition in the Islamic rules of arbitration is not restricted to the parties' acceptance (Oseni, 2016).

Although Islamic banking disputes should be based on Islamic law, the rules that governs the arbitration mechanism in resolving the Islamic banking disputes are still to this day derived from conventional laws such as Act 646 and I-Arbitration Rule 2018, which was modeled based on the UNCITRAL Model Law. Hence, lawmakers should consider the nature of Islamic banking cases and create new arbitration rules that are entirely derived from Islamic laws.

\section{Enforcement of Arbitral Awards}

The popularity of arbitration as a mechanism to resolve Islamic banking disputes have grown considerably due to its many advantages. However, the parties would not appreciate nor consider arbitration as a substitute to court proceedings, if the arbitral decisions are not enforced with the same or at least with equivalent effect as the court's judgment (Nacimiento \& Barnashov, 2010).

Consequently, many international treaties and conventions have been legislated to guarantee that the arbitral award is enforced fully with the power of the law. One example is the legislation of the arbitral awards in the New York Convention on the Recognition and Enforcement of Foreign Arbitral Awards 1958 (hereinafter referred 
to as NY Convention). NY Convention strives to guarantee that the foreign arbitration awards from the participating countries are recognised and enforced by the courts in their respective jurisdiction. Malaysia signed the NY Convention on $5^{\text {th }}$ November 1985.

Furthermore, Act 646 does not differentiate between national and international arbitral awards with regards to the requirements for recognition and enforcement (Arbitration Act 2005, s.38). However, the national courts in Malaysia may reject the recognition and enforcement of an arbitral award in certain circumstances (Act 646, s.39(1)(a) and (b)).

Although Act 646 provides considerable certainty for the disputants who strives to enforce an arbitral award, the court is in its discretion to refuse the enforcement of an arbitral award even though it is against public policy in Malaysia. (Act 646, s.39(1)(b)(ii)).

Thereby, the binding nature of the arbitral awards play an important role in making arbitration a perfect and unique mechanism for the settlement of any type of dispute, and is a notable alternative to litigation as an enforceable and binding avenue (Hörnle, 2009), as compared to other ADR mechanisms such as mediation and negotiation which have not provided a binding and enforceable decision.

However, it is also suggested that arbitration may not always be a suitable option for parties to resolve international Islamic banking dispute as different countries have adopted different arbitration laws. In other words, disputes that violates the public policy in Malaysia, may not be violating the public policy in a different country.

For instance, a dispute regarding the contract of Bay' $a l$ - 'Inah, ${ }^{2}$ was initiated between (A) a Malaysian Islamic financial client and (B) an Islamic Bank located in Saudi Arabia. The parties had agreed beforehand that Malaysia is a seat of arbitration, and proceeds to the arbitral tribunal that delivers its decision in favour of (A), who then takes a flight to Saudi Arabia to enforce the award. However,

2 The sale and buy-back of an asset for a higher price than that for which the seller originally sold it. A seller immediately buys back the asset he has sold on a deferred payment basis at a price higher than the original price. 
the National Court of Saudi Arabia refused the enforcement of the arbitral award on the grounds (according to Article V (2) (b) of NY Convention) that the Bay'al- 'Inah contract is completely prohibited and is against the Shariah law and public policy of Saudi Arabia. In contrast, such contract of Islamic transaction is permitted in Malaysia. Hence, such a situation will raise issues of legal conflict between the two parties (refusing to enforce the arbitral award because it is against the public policy in Saudi Arabia).

Subsequently, it is proposed that to enhance the use of arbitration in resolving international Islamic banking disputes without any difficulties, during the first stage of arbitration, the parties to the international Islamic banking dispute should consider the applicable law of the country where an arbitral award would be enforced before entering into an arbitration agreement i.e "Lex Loci Executionis". This is crucial to ensure that their arbitral award is enforceable and does not violate any public policy of the countries. During the second stage, the main players in the Islamic financial industry should attempt to coordinate their arbitration laws by adopting a uniform law that is consistent between the countries.

\section{Traditional Arbitration is not Suitable Option to the Small- Claim of Dispute}

Generally, the settlement of small-claim disputes are not available in the traditional methods of dispute resolution because the monetary limit for the registration of commercial cases are usually mentioned in the judicial statute (Oseni \& Omoola, 2015). In Malaysia, the courts' jurisdiction to decide on the dispute is based on monetary jurisdiction as the court is unable to award or grant damages in excess of the extent that has been assigned to it (Hasshan, 2016). Smaller claims are adjudicated by the Malaysian lower court, while larger claims are usually adjudicated by the Malaysian high court (Hasshan, 2016).

For instance, the Second Class Magistrate Courts has its civil jurisdiction for claims that does not exceed ten thousand ringgits (Subordinate Court Act 1948, s.92). The First Class Magistrate Courts have civil jurisdiction whereby the disputes, or value of the subject matter does not exceed one hundred thousand ringgits 
(Subordinate Court Act 1948, s.90). Meanwhile in the Sessions Court, it civil jurisdictions with regards to disputes, or the value of the subject matter must not exceed RM1 million (Subordinate Court Act 1948, s.65). Subsequently, in cases whereby the amount exceeds RM1 million is filed at the High Court (Hasshan, 2016).

The Malaysian government has made great progress in establishing the Commercial Division 4 of Kuala Lumpur High Court, which is a specialized court that handles and adjudicate Islamic finance cases. These Islamic finance cases will then be subjected to the monetary jurisdiction of the courts. Hence, Islamic finance cases can be registered at all levels of civil courts namely Magistrates' courts, Sessions courts and High Courts, based on the value of claims involved (Hasshan, 2016).

As mentioned previously, the parties to Islamic banking disputes may hesitate before submitting their dispute to arbitration, as it is an expensive mechanism. Furthermore, the high costs of arbitration has caused disputants to avoid this mechanism, especially when the amount of the claims for the dispute is small (Spatt, 1998). In the context of Malaysia, the disputants and arbitral tribunal have the authority to agree on the arbitral tribunal's fees and expenses, known as "fees agreement" during the 30 days from the time the arbitral tribunal is appointed (I-Arbitration Rule, article 14(4)). However, in the situation where the parties and the arbitral tribunal fail to reach a "fees agreement", the fees will be determined by the Director of AIAC in accordance with Schedule 1 (I-Arbitration Rule, article $14(2)$ ) that is based on the amount in dispute (I-Arbitration Rule, article 14(7)).

Schedule 1: The Arbitrator's Fees and Administrative Fees Based On the Amount in Dispute in Both Domestic and International Dispute Under I-Arbitration Rule 2018.

\begin{tabular}{lccc}
\hline $\begin{array}{c}\text { Type Of } \\
\text { Arbitration }\end{array}$ & $\begin{array}{c}\text { Amount In } \\
\text { Dispute }\end{array}$ & $\begin{array}{c}\text { Arbitrator's } \\
\text { Fees }\end{array}$ & $\begin{array}{c}\text { Administrative } \\
\text { Fees }\end{array}$ \\
\hline Domestic & Up to RM 150,000 & RM 11,200 & RM 6,600 \\
International & Up to $\$ 50,000$ & $\$ 3,500$ & $\$ 2,050$ \\
\hline
\end{tabular}


Assuming that a domestic dispute transpires between Bank Islam and (X) Islamic financial customer and the amount of the dispute is only RM 20,000, then it would be inappropriate for the parties to arbitrate their dispute under AIAC (only in cases when the parties and arbitral tribunal do not agree on "fees agreement", whereby the Director of AIAC can apply a more suitable amount in dispute as mentioned in schedule 1). Unfortunately, the expenses of using arbitration under the AIAC is somewhat similar to the amount of the claims the parties may receive from the dispute. Thus, it can be argued that arbitration through the AIAC is not a suitable option for parties to settle small amount disputes effectively.

In addition, questions have been raised on the need to use arbitration to resolve Islamic banking disputes, despite Malaysia having provided several out-of-court options to resolve Islamic banking disputes such as the dispute resolution mechanisms provided by the Ombudsman for Financial Services (OFS). Therefore, this paper analyses the challenges that are faced by the other alternative dispute resolution mechanisms in the context of Islamic banking disputes. Literature have shown that the other ADR mechanisms have been subjected to various criticisms (Abdul-Qadir Zubair, 2014).

This paper has concluded that the cost of using arbitration and the amount of the claims are interrelated elements, as mentioned in Schedule 1 of I-Arbitration Rules 2018. In short, if the amount in dispute is low, the fees for arbitrators and the administrative fees will be low. Therefore, to facilitate the settlement of small-claim disputes through the arbitration mechanism, lawmakers may have to provide new categories to the disputants for the amount in dispute such as (up to RM 10.000), (up to RM 50.000) and (up to RM 100.000). In doing so, the use of arbitration would be more available and convenient for small-claim disputes.

\section{Judicial Intervention}

There are two types of judicial intervention in arbitral proceedings. The first is a beneficial intervention, such as obtaining an order from the High Court regarding the attendance of a witness to provide evidence (Act 646, s.29(2)). The second is a malignant or excessive intervention which leads to unnecessary delays, uncertainties and 
high costs which can be avoided, with the purpose to invariably convert 'arbitration into a virtual litigation' (Rasyid, 2005). The excessive intervention, or localisation of arbitral proceedings would give the national courts the right to intervene in the arbitral proceedings. In contrast, delocalisation suggests that the national courts, under national laws, has no authority to intervene in the arbitration proceedings.

In Malaysia, the objective of Act 646 is to reduce the judicial intervention by the national courts and to minimize the courts interference in the arbitral awards and proceedings, however, under certain circumstances, Act 646 does permit judicial intervention to some extent (Act 646, s.8). For instance, it has been noted that the Malaysian High Court has the right to grant several types of interim measures in arbitral proceedings (Act 646s.11).

Moreover, the High Court is permitted to use its authority on domestic and international arbitration (Act 646, s.11(3)). However, it is unclear on the number of times a party can apply to a High Court for an interim measure.

It is worth noting that Act 646 has been considered a significant legal development that is recorded in Malaysian legal history as it has succeeded in reducing the intervention of the courts in arbitration, when compared to the Arbitration Act 1952 (Act 93) (Idid \& Oseni, 2014). For example, in the case of Taman Bandar Baru Masai Sdn Bhd v Dindings Corporations Sdn Bhd [2010] 5 CLJ 83, the court upheld the Arbitration Act 2005 (Act 646) that prevented courts from intervening with the arbitral awards, and subsequently ordered every court to abstain from intervention in this case. However, the court can intervene if there were any tampering that led to an unjust verdict in the case.

Thus, it can be concluded that the courts in Malaysia seek to provide a supportive role to the arbitral process, rather than a destructive role. However, there are still gaps in the current Act that need to be addressed by lawmakers. This is to avoid the possibility of exploitation and misuse by parties that choose arbitration as the mechanism to resolve Islamic banking disputes. 


\section{CONCLUSION}

There is little doubt for the need of a flexible and Shariah-compliant arbitration that is crucial in ensuring the sustainability and growth of the Islamic finance industry. Although the existing legislative frameworks that govern arbitration in Islamic banking disputes have achieved its targets in making Malaysia as a preferred seat for arbitration, some issues still exist that needs to be immediately addressed by the relevant authority. The judicial authorities in Malaysia would need to take the initiative to reform several legislation, in order to avoid any uncertainties and be more Shariacompliant. Hence, stringent measures should be taken to mitigate the financial, physical and mental burden on parties that opted for arbitration in Islamic banking disputes to ensure access to justice through the reduction of cost, time and formality.

\section{REFERENCES}

The Star. (2013, June 23). Arbitration in Malaysia: Taking it to the next level. The Star. Retrieved from https:/www.thestar.com. $\mathrm{my} /$ news/nation/2013/06/23/arbitration-in-malaysia-takingit-to-the-next-level/.(accessed June 15, 2018).

Ab. Halim, M. 'A. (2011). Enhancing the effectiveness of legal infrastructure: A study on legal issues and other challenges of Islamic banking and finance in Malaysia. Paper from 8th International Conference on Islamic Economics and Finance. Center for Islamic Economics and Finance, Qatar Faculty of Islamic Studies, Qatar Foundation, 19-21.

Abdul-Qadir Zubair, A. (2014). A critical analysis of the dispute resolution mechanisms in the islamic finance industry in Malaysia (Unpublished doctoral dissertation), Ahmad Ibrahim Kulliyyah of Laws, International Islamic University Malaysia.

Abraham, C. (2006). Alternative dispute resolution in Malaysia. Paper from 9th General Assembly of the Asian Law Association. Bangkok, Thailand, 1-25.

Abu Backer, H. S. (2017). Arbitration clause in Islamic finance facility: A New York Convention and Model Law perspective. Middle East Insights, 166 (6), pp. 1-9. 
Alam, S. (2014). Commercial arbitration: Factors making it lose out against other processes. Middle East Journal of Business, 9(2), 51-59.

Al-Qur'an.

Al-Shibli, F. S. (2017). The role of arbitration in settling the dispute of Islamic banking. Journal of Humanities, Language, Culture and Business, 1(2), 221- 229.

Asouzu, A. A. (2001). International commercial arbitration and African states: Practice, participation and institutional development. United Kingdom: Cambridge University Press.

Dahlan, N. K. (2018). Alternative dispute resolution for Islamic finance in Malaysia. Paper presented in Malaysia Technical Universities Conference on Engineering and Technology, 150. Malaysia, Kuala Lumpur, 1-4.

Friedland, P., \& Mistelis, L. (2015). 2015 International arbitration survey: Improvements and innovations in international arbitration. White case. Retrieved from https://www. whitecase.com/publications/insight/2015-internationalarbitration-survey-improvements-and-innovations

Goode, R. (1992). The adaptation of English Law to international commercial arbitration. Arbitration International, 8(1), pp. $1-15$.

Hassan, R., \& Hussain, M. A. (2011). The establishment of Muamalat court in Malaysia. IIUM Law Journal SEd, 119-135.

Hasshan, H. (2016). Islamic finance litigation: Problems within the Malaysian civil courts structure. Jurnal Undang-Undang dan Masyarakat, 121(20), pp. 33-42.

Herboczková, J. (2008). Amiable composition in the international commercial arbitration. The Masaryk University, 1(3), 1-11.

Hodges, P., Kaplan, C., \& Godwin, P. (2012). KLRCA's New I-Arbitration Rules: A new option for islamic finance parties. Lexology. Retrieved from http://www.lexology.com/library/ detail.aspx?g=f95ce493-1569-4011-8a90-9d560cb13b48

Hörnle, J. (2009). Cross-border internet dispute resolution. United Kingdom: Cambridge University Press.

Idid, S. A. (2004). Alternative Dispute Resolution (ADR) an alternative access to justice. In Syed Khalied Rashid \& Syed Ahmad Idid (Ed.), In conference proceeding of mediation \& arbitration in Asia Pacfic. Malaysia-IIUM, pp.203-209. 
John Shijan, M. O. (1999). Non-judicial means of dispute settlement. In Guiguo, W. \& John, M.O. (Eds.), Chinese Law. The Hague: Kluwer Law International.

Karim, N. K. (2017, Oct 27). "British national, 73, jailed six months and fined by KL court for cheating." New Straits Times. Retrieved from https://www.nst.com.my/ news/2017/01/202042/british-national-73-jailed-six-monthsand-fined-kl-court-cheating

Kaufmann-Kohler, G., \& Schultz, T. (2015). The use of information technology in arbitration. Jusletter, 32(1), 1-127.

Kawamura, A. (2017). Comparison of Malaysia-Dubai approach for the Islamic dispute resolution system in Islamic finance. Jurnal Hadhari (SEd), 57-66. <http://ejournals.ukm.my/ jhadhari/issue/view/990>.

Lahoti, R. C. (1999). The new law of arbitration and the challenges before the legal community. ICA Arbitration Quarterly, 37(1), 3-11.

Leong, C. Y., \& Mann, J. C. F. (2012). The Asia-Pacific arbitration review 2013. Global Arbitration Review. Retrieved from https://globalarbitrationreview.com/insight/the-asiapacificarbitration-review-2013/1036720/malaysia

Meyer, B. F. (2011). Formalism in arbitration - Good or evil? In Wirth, M., Rouvinez, C., \& Knoll, J. (eds.). The search for "truth" in arbitration is finding the truth what dispute resolution is about?. pp.135-146 http://www.jurispub.com/

Miskam, S., \& Abd Hamid, N. A (2011). Alternative dispute resolution in Islamic finance: From adversarial to nonadversarial. Paper presented in The Asian Business and Management Conference. Osaka, Japan, 224-234.

Nacimiento, P., \& Barnashov, A. (2010). Recognition and enforcement of arbitral awards in Russia. Journal of International Arbitration, 27(3), 295-306.

Ng Min Shen. (2017 August 21). Growing the Islamic banking business. The Malaysian Reserve. Retrieved from <https:// themalaysianreserve.com/2017/08/21/growing-islamicbanking-business/

Olayemi, A. A. M., \& Bandar Khalid al-Zabyani, B. K. (2014). Arbitration clause in Islamic banking contracts: A contractual necessity. International Journal of Interdisciplinary and Multidisciplinary Studies, 1(7), pp. 1-6. 
Oseni, O. A. (2009). Dispute resolution in Islamic banking and finance: Current trends and future perspectives. Paper from International Conference on Islamic Financial Services: Emerging opportunities for law/economic reforms of the developing nations, University of Ilorin. Nigeria, 1-25.

Oseni, U. A. (2016). Islamic finance arbitration: Integrating the classical and modern legal frameworks. Baizura Abd Razak (Eds.), Islamic Banking and Finance: Principles, Instruments and Operations. The Malaysian Current Law Journal Sdn Bhd, pp. 549-568. Retrieved from http://irep.iium.edu. my/47652/1/47652.pdf\%5Cnhttps://www.researchgate.net/ publication $/ 289519462$

Oseni, U.A., \& Omoola, S. O. (2015). Banking on ICT: The relevance of online dispute resolution in the Islamic banking industry in Malaysia. Information \& Communications Technology Law, 24(2), 1-19.

Rajoo, S. (2009). Institutional and ad hoc arbitrations: Advantages and disadvantages. The Law Review, 547-558.

Rashid, S. K. (2005). Some contentious issues in international commercial arbitration. International Islamic University Malaysia Law Journal, 13(2), 147-166.

Rashid, S. K. (2008). How 'Stay of Arbitration' could bring about quicker and cheaper settlement of commercial disputes. The Law Review, 265-272.

Spatt, D. M. (1998). What's so good about arbitration?. Arts Law. Retrieved from http://www.artslaw.org/arb.htm

Syed A Rahman, S. F. H., \& Mokhtar, K. A. (2017). The financial ombudsman scheme as an alternative dispute resolution mechanism for financial disputes: The Malaysian experience. Paper from ICDR: Modern trends in effective dispute resolution. Ahmad Ibrahim Kulliyyah of Laws, International Islamic University Malaysia, Kuala Lumpur, pp. 387-398.

Wan Muhammad, R. (2008). The theory and practice of Sulh (Mediation) in the Malaysian Shariah Court. IIUM Law Journal, 16(1), 33-38.

Welser, I., \& Wurzer, S. (2008). Formality in international commercial arbitration - For better or for worse? In Klausegger, Klein, Kremslehner, Petsche, Pitkowitz, Power,Welser \& Zeiler (Eds.) Austrian Arbitration Yearbook. pp. 222-236. Retrieved from http://www.chsh.com/fileadmin/docs/publications/Welser/ Beitrag_Welser_2008.pdf 
Yu, L. (2008). Amiable composition - A learning curve. Journal of International Arbitration. 17(1), 79-98.

Zakaria, A. (2013). A judicial perspective on Islamic finance litigation in Malaysia. IIUM Law Journal, 21(2), 143-182.

Lee, M. J., \& Oseni, U. A. (2015). IFSA 2013: Commentaries on Islamic banking and finance. Malaysian Current Law Journal Sdn. Bhd.

Engku Ali, E. R. A., \& Oseni, U. A. (2017). Towards an effective legal and regulatory framework for Islamic financial transactions major initiatives of the Central Bank of Malaysia. International Journal of Law and Management, 59(5), 652672.

Mohamed, A. M. T. et al.. (2015). Arbitration as a method of dispute settlement in Islamic banking and finance: A perspective from Malaysian governing law. Pertanika Journal of Social Sciences and Humanities, 23(11), 153-164.

Olayemi, A. A. M., Mahamood, S. M. \& Buang, A. H. (2017). Neojudicial procedure for adjudication and arbitration on Islamic financial cases: Reference to Shariah council on Shariah matters. Malayan Law Journal, 108(1), 1-12.

Idid, S. A., \& Oseni, U. A. (2014). The Arbitration (Amendment) Act 2011: Limiting court intervention in arbitral proceedings in Malaysia. The Malayan Law Journal, 2(7), 1-22. 